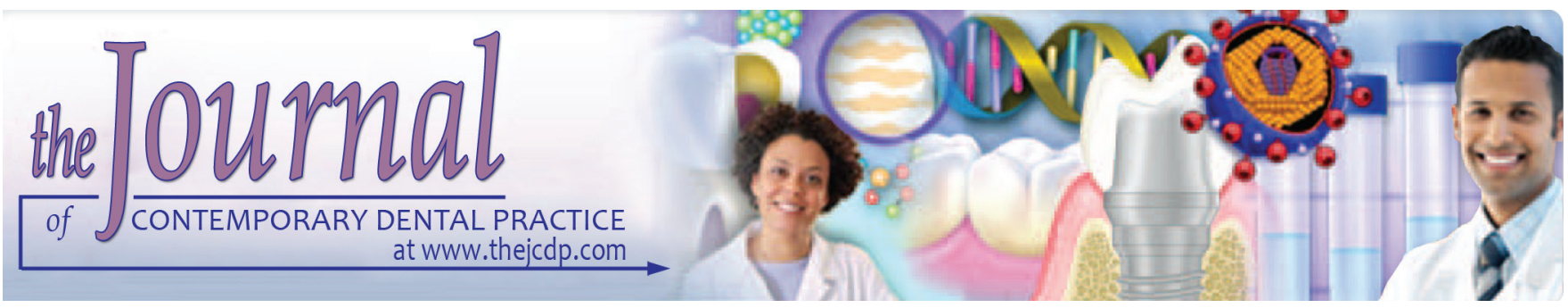

\title{
Evaluating the Effect of Different Impression Techniques and Splinting Methods on the Dimensional Accuracy of Multiple Implant Impressions: An in vitro Study
}

${ }^{1}$ Harpreet S Saini, ${ }^{2}$ Shashikala Jain, ${ }^{3}$ Sandeep Kumar, ${ }^{4}$ Rajnish Aggarwal, ${ }^{5}$ Sunita Choudhary, ${ }^{6} \mathrm{~N}$ Kulashekar Reddy

\begin{abstract}
Aim: This study was done to determine more accurate impression technique and splinting method for multiple implant impressions in edentulous patients.
\end{abstract}

Materials and methods: A prefabricated maxillary reference model was taken on which four implants were placed parallel to each other using vertical milling machine. Forty custom trays having different tray designs were fabricated using autopolymerizing acrylic resin on the stone cast obtained from the reference model. A total of 40 samples $(n=40)$ were divided into five groups, in which group I included casts obtained from impressions made with closed-tray technique, group II: open-tray impression technique, group III: open-tray impressions splinted with acrylic, group IV: open-tray impressions splinted with light cure material, and group $\mathrm{V}$ acted as a control group (reference model). Casts obtained were poured with dental stone. The interimplant distances were checked using coordinate measuring machine to evaluate the three-dimensional (3D) positional accuracy in $\mathrm{X}, \mathrm{Y}$, and $\mathrm{Z}$ axes.

Results: Casts obtained from impressions made with closedtray technique showed highest mean deviation from the reference model while those obtained from open-tray splinted with light cure showed the least deviation. The casts obtained from open-tray nonsplinted and open-tray acrylic splinted showed intermediate mean deviations.

Conclusion: The casts obtained from open-tray impression technique were more accurate as compared with the closedtray technique. Among splinting, the impressions obtained from light cure splinting showed more accuracy than the impressions obtained from acrylic splinting.

\footnotetext{
${ }^{1-5}$ Department of Prosthodontics, Surendera Dental College \& Research Institute, Sri Ganganagar, Rajasthan, India

${ }^{6}$ Department of Prosthodontics, College of Dentistry, Jazan University, Jazan, Kingdom of Saudi Arabia

Corresponding Author: Harpreet S Saini, Department of Prosthodontics, Surendera Dental College \& Research Institute Sri Ganganagar, Rajasthan, India, Phone: +919501814099 e-mail: Dr.harpreet8@gmail.com
}

Clinical significance: The accuracy of the multiple implant impression is influenced by the type of impression material used which ultimately leads to an accurate cast on which precisely fitting prosthesis is fabricated. Several factors including material accuracy, time span before the impression is poured, and extent of intraoral undercuts are to be kept in mind while choosing an impression material.

Keywords: Dental implant, Dental impression, Dimensional measurement accuracy, Polyvinyl siloxane.

How to cite this article: Saini HS, Jain S, Kumar S, Aggarwal R, Choudhary S, Reddy NK. Evaluating the Effect of Different Impression Techniques and Splinting Methods on the Dimensional Accuracy of Multiple Implant Impressions: An in vitro Study. J Contemp Dent Pract 2018;19(8):1005-1012.

Source of support: Nil

Conflict of interest: None

\section{INTRODUCTION}

The anatomy of the residual ridges determines the orientation for implant placement. Any inaccuracy in impression will cause misfit of the prosthesis, which can cause further problems, such as mechanical and/or biological complications. However, marginal discrepancy due to the prosthesis misfit may further lead to enhanced accumulation of plaque, which affects the surrounding soft or hard tissues. ${ }^{1}$ Literature shows that the accuracy of the implant impression cast depends on many factors: the type of material used, impression technique, angulations, number, use of splinting, and airborne abrasion of the impression copings. The ultimate goal should be to fabricate a prosthesis that does not transfer stress to the implant when fully seated. ${ }^{2}$ The impression can be made in two ways: one is abutment level and the other is implant level. It can be done by using two methods, the direct method, also called as open-tray or pick-up 
technique, and indirect method (closed-tray or reposition technique). The indirect or closed-tray technique is less difficult, but it has greater instability in transfer of implant positions. In the open-tray technique, impression copings are allowed to remain inside the implant impression. By using this technique, the implant angulation effect and the chances of material deformation when recovered from mouth are reduced; moreover, there is no reinsertion of the impression coping back into the impression. ${ }^{3}$ During clinical and laboratory phases, inaccuracy in transferring 3D orientation of implants to the cast can be detected due to the movement of impression copings. The splinting of transfer copings and modifications are emphasized to reduce this movement. Splinted direct technique was found to be the most accurate for multiunit nonparallel implants. Splinting of the copings can be done by using acrylic resin, plaster, or composite resins. ${ }^{3}$

In the literature, there have been conflicting results regarding the use of splinting and different impression techniques in implants. So, the purpose of this study is to check the accuracy of multiple implant impressions by studying the effect of different implant impression techniques and splinting methods.

\section{MATERIALS AND METHODS}

The study was conducted on a prefabricated maxillary dummy model used as reference model. A vertical milling machine was used to hold the cast and drill holes of required depth, diameter, and angulation. A $3.5 \mathrm{~mm}$ twist drill was incorporated to prepare the holes. The four implants were placed into the master cast (Fig. 1). Two implants in the right and left canine region and the other two in the right and left first molar region were placed on the reference model. Sequential numbering of implants was done from left to right. A total of 40 samples $(n=40)$ were taken and were divided into five groups, in which group I included casts obtained from impressions made with closed-tray or indirect impression technique, group II: open-tray or direct impression technique, group III: open-tray impressions splinted using floss with acrylic, group IV: open-tray impressions splinted using floss with light cure material and group $\mathrm{V}$ acted as a control group which included measurements of reference model.

\section{Custom tray Fabrication}

An alginate impression of reference model was made and a primary cast was poured in dental stone and was used for the production of the custom trays. The cast was covered by two layers of base plate wax that allowed consistent thickness of impression material. Palatal region and the land area act as stop, and further modifications in the tray design were done according to the open- and closed-tray impression procedures. For closed-tray impression technique, four wax pillars each having height exactly $2 \mathrm{~mm}$ above the height of the impression copings were placed over the implant sites and duplication of the model was done with alginate. The impression was poured with dental stone (type III). The cast thus obtained was used to fabricate 10 custom trays that were used to make impressions for group I (Fig. 1B). For open-tray impression technique that was performed in two different groups, i.e., with and without splinting, a wax rim was built having $11 \mathrm{~mm}$ height, such that the screws of the open-tray copings were easily accessible after custom tray fabrication and an overall width of 6 to $8 \mathrm{~mm}$ was provided for better splinting. A total of 30 custom trays were fabricated for this technique. Access holes were drilled in all the four implant positions (Fig. 1C).

\section{Impression Making}

The 3M ESPE (St. Paul, MN) adhesive was used to paint the custom trays using brush supplied by manufacturer and was left to dry for 15 minutes. Light body vinyl polysiloxane (VPS) was gunned onto the reference model using mixing tips on automixing impression gun (3M ESPE). The VPS putty material (3M ESPE) was loaded to the custom trays and seated on the master cast, making sure that each tray touched the land area on the reference model. Instantly after placing the tray over the model, any excess material was removed to verify the complete seating of each tray. Once sufficient setting time was attained, impression was removed and transfer copings were unscrewed.

\section{Group I (Closed-tray Impressions)}

After making impression with the VPS material, analogues were fastened onto the copings and reinserted into the impression. Any remaining excess material was trimmed with a sharp no. 11 scalpel blade flush with the borders of the tray.

\section{Group II (Open-tray)}

Once the impression was made, the copings were unscrewed, then the tray was separated from the reference model while the impression copings remained inside the impression. An implant analog was connected to the hex and the copings were hand tightened.

\section{Group III (Open-tray Splinted with Acrylic)}

The transfer copings were connected by tying them with dental floss (Fig. 1D) and splinting was done with autopolymerizing self-cure acrylic resin (Pyrex Ltd.) and 

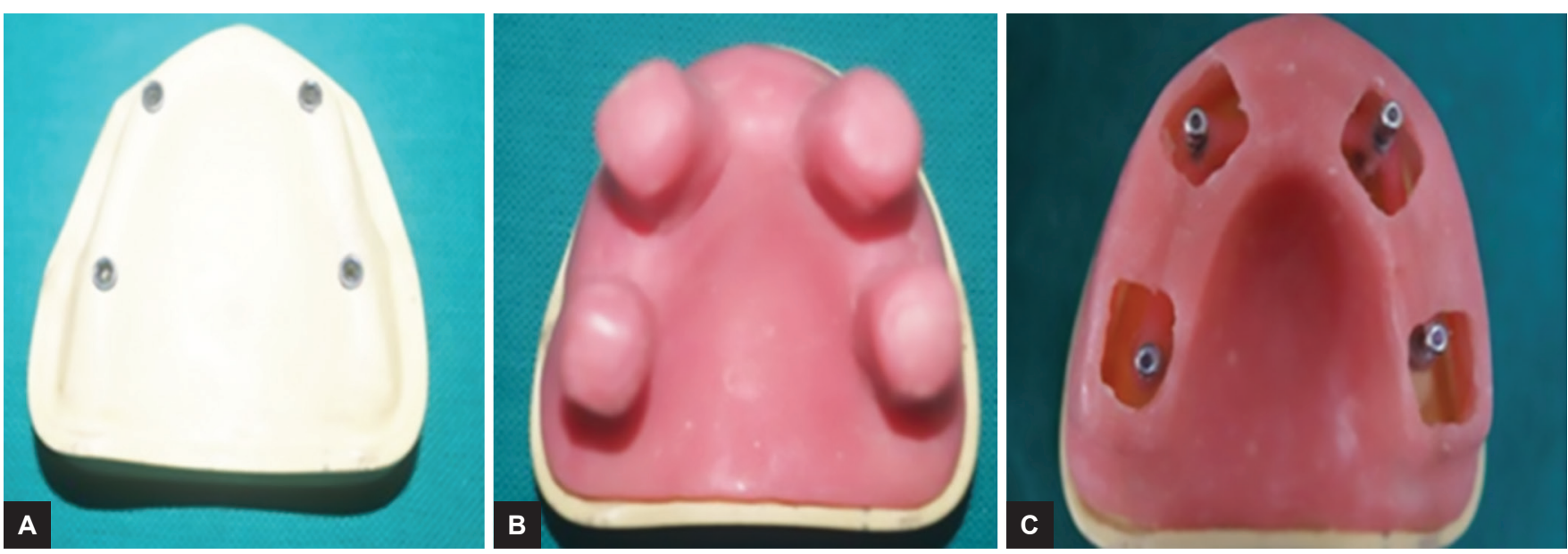

Figs 1A to C: (A) Reference implant model; (B and C) closed- and open-tray designs fabricated
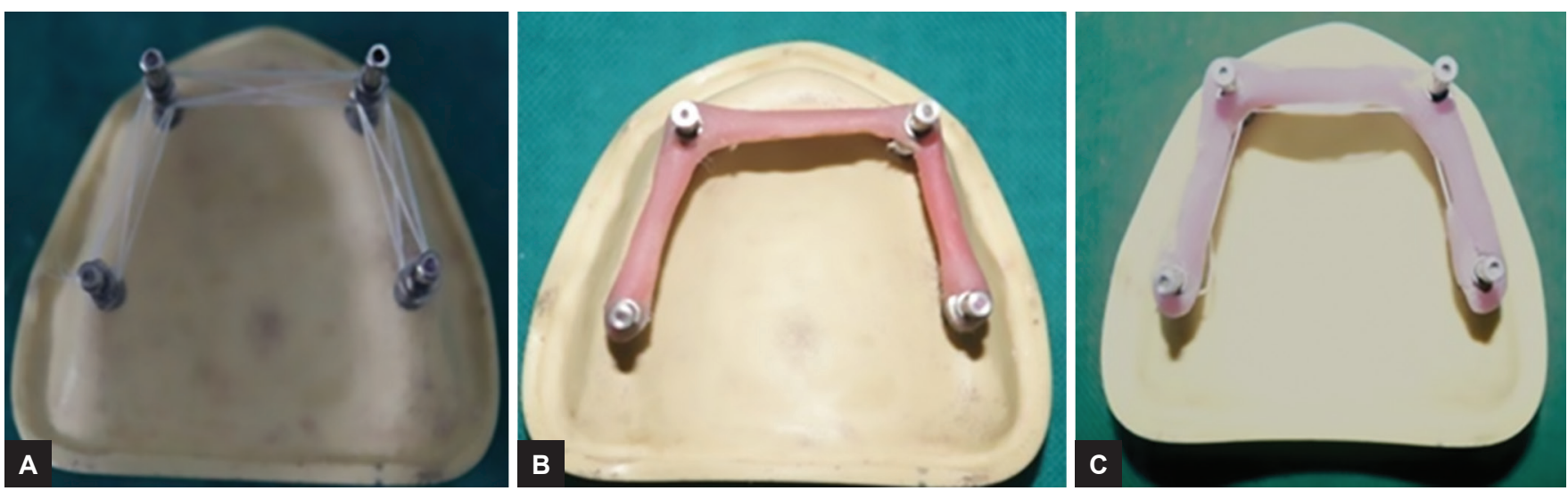

Figs 2A to C: (A) Scaffolded floss for the stabilization of splinting material; (B) splinted with acrylic resin;

(C) splinted with light cure material

allowed to polymerize for 17 minutes (Fig. 2A). Splinting was done from the first square to the second square; 17 minutes after setting, the final impression procedure was accomplished.

\section{Group IV (Open-tray Splinted with Light Cure Material)}

Impression copings were tightened and were tied up with dental floss. Splinting was done using light cure tray material (Plaque Photo, WP Dental). After the application of tray material, the reference model was light cured (Liva light, WP Dental Germany) for 7 minutes. Once the curing was done, the final impression procedure was accomplished (Fig. 2B).

Impressions were checked for inaccuracies and if required were repeated. For all the groups, impression pouring was done using dental stone. Dental stone was mixed with water according to the manufacturer's recommendation. Mechanical vacuum mixer and a vibrator (Whip Mix Corporation, Louisville, KY) were used to pour the cast. Once adequate setting time was obtained casts were separated.
All casts were subjected to measurement using a coordinate measuring machine (CMM STRATO Bright 710, Mitutoyo Corporation) having an accuracy of less than $0.0001 \mathrm{~mm}$ for the $\mathrm{X}, \mathrm{Y}$, and $\mathrm{Z}$ axes. All measurements were performed using probe head (PH10M Mitutoyo Corp. Japan) and a signal probe (TP7M Mitutoyo Corp. Japan) on Geopak-win software (Mitutoyo Corporation, Tokyo, Japan). The coordinate system applied for this study was defined as follows:

The center of fixture or analog 1 was designated as the origin of coordinated system. Three values were recorded for every interimplant distance in the $X, Y$, and $Z$ axes for every cast, and then the mean values of all measurements were obtained. The centers of the implant replicas were measured first by marking four points on the periphery of the implant replicas. Implant analog 1 was kept as the reference, and all measurements were done with reference to this analog. The distance between the centers of implant analogs 1 and 2, 1 and 3, and 1 and 4 was determined in the $\mathrm{X}$-axis (Fig. 3A). For the Y-axis, implant replicas 1 and 4 were used to form a reference line. From this reference line, distance D2y and D3Y were measured (Fig. 3B). The 


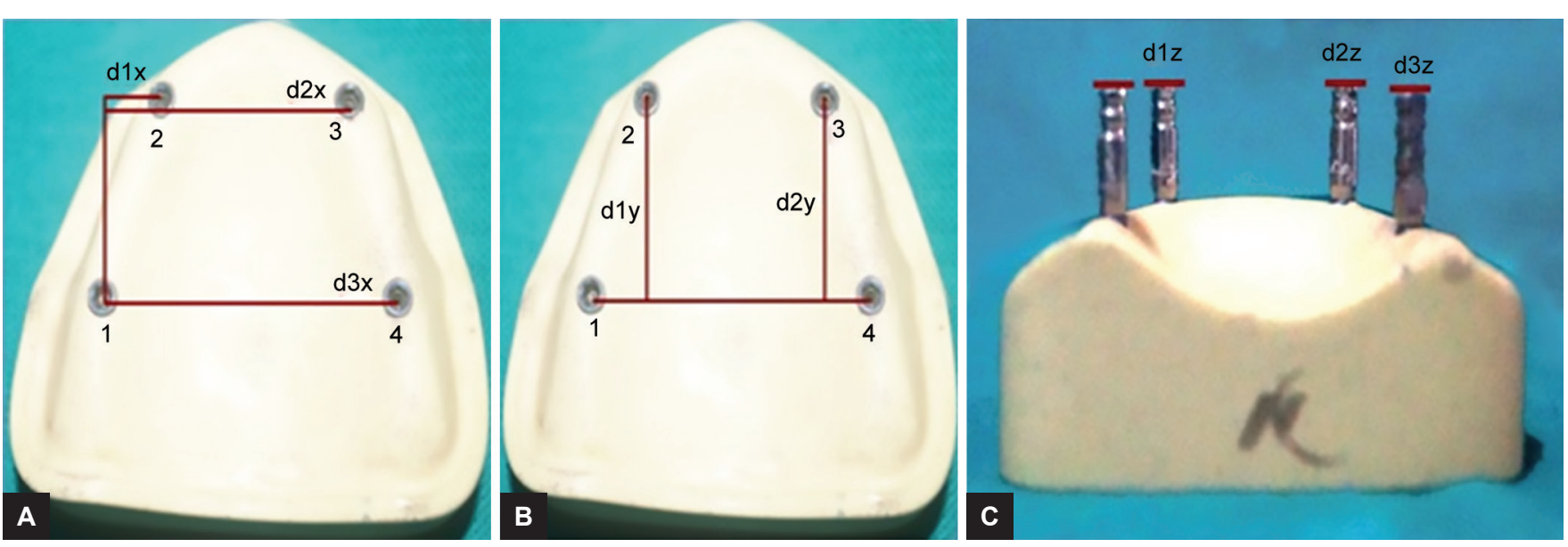

Figs $3 \mathrm{~A}$ to $\mathrm{C}$ : Schematic diagrams representing the measurements made in $\mathrm{X}, \mathrm{Y}$, and $\mathrm{Z}$ axis respectively

distances between the lines formed by planes of implant replicas 1 and 2, 1 and 3, and 1 and 4 were measured to obtain the interimplant distance in the Z-axis (Fig. 3C). The master cast values thus obtained were compared with those from the reference model. The values were statistically evaluated using one-way variance analysis (ANOVA) and post hoc test.

\section{RESULTS}

Tables 1 to 3 and Graph 1 show differences ( $\mathrm{mm}$ ) in interimplant distance measured in the X-axis. In $\Delta \mathrm{d} 1 \mathrm{X}$, group IV $(\Delta \mathrm{d} 1 \mathrm{X}=0.17)$ had least mean difference followed by group III $(\Delta \mathrm{d} 1 \mathrm{X}=0.62)$, group II $(\Delta \mathrm{d} 1 \mathrm{X}=0.75)$, and group I $(\Delta \mathrm{d} 1 \mathrm{X}=3.53)$. In $\Delta \mathrm{d} 2 \mathrm{X}$, group IV $(\Delta \mathrm{d} 2 \mathrm{X}=0.21)$ had least mean difference followed by group III $(\Delta \mathrm{d} 2 \mathrm{X}=$ $0.063)$, group II $(\Delta \mathrm{d} 2 X=0.82)$, and group $\mathrm{I}(\Delta \mathrm{d} 2 \mathrm{X}=2.54)$. In $\Delta \mathrm{d} 3 \mathrm{X}$, group IV $(\Delta \mathrm{d} 3 \mathrm{X}=0.48)$ had least mean difference

Table 1: Intergroup statistical comparison using ANOVA and post hoc test for $\mathrm{D} 1 \mathrm{X}$ values

\begin{tabular}{|c|c|c|c|}
\hline & $D 1 X$ & ANOVA & \\
\hline Groups & Mean $\pm S D$ & & $p$-value \\
\hline Group I (closed tray) & $11.63 \pm 2.04$ & 9.13 & $<0.01$ \\
\hline Group II (open tray) & $8.85 \pm 1.21$ & & \\
\hline Group III (acrylic splint) & $8.72 \pm 1.19$ & & \\
\hline Group IV (light cured) & $8.27 \pm 0.9$ & & \\
\hline Group V (control) & $8.1 \pm 0$ & & \\
\hline
\end{tabular}

Tukey honest significant difference post hoc test; SD: Standard deviation; Groups I vs II: Diff $=2.7800,95 \%$ confidence interval $(\mathrm{Cl})$ $=-4.5788$ to $-0.9812, p=0.0007$; Groups I vs III: Diff $=2.9100$, $95 \% \mathrm{Cl}=-4.7088$ to $-1.1112, \mathrm{p}=0.0004$; Groups I vs IV: Diff $=$ $3.3600,95 \% \mathrm{Cl}=-5.1588$ to $-1.5612, \mathrm{p}=0.0000$; Groups I vs V: Diff $=3.5300,95 \% \mathrm{Cl}=-7.7485$ to $0.6885, \mathrm{p}=0.1379$; Groups II vs III: Diff $=0.1300,95 \% \mathrm{Cl}=-1.9288$ to $1.6688, \mathrm{p}=0.9996$; Groups II vs IV: Diff $=0.5800,95 \% \mathrm{Cl}=-2.3788$ to $1.2188, \mathrm{p}=$ 0.8851; Groups II vs V: Diff $=0.7500,95 \% \mathrm{Cl}=-4.9685$ to 3.4685 , $\mathrm{p}=0.9858$; Groups III vs IV: Diff $=0.4500,95 \% \mathrm{Cl}=-2.2488$ to $1.3488, p=0.9509$; Groups III vs V: Diff $=0.6200,95 \% \mathrm{Cl}=$ -4.8385 to $3.5985, p=0.9931$; Groups IV vs V: Diff $=0.1700,95 \%$ $\mathrm{Cl}=-4.3885$ to $4.0485, \mathrm{p}=1.0000$ followed by group III $(\Delta \mathrm{d} 3 \mathrm{X}=0.55)$, group II $(\Delta \mathrm{d} 3 \mathrm{X}=$ $0.75)$, and group $I(\Delta d 1 X=2.63)$. The post hoc test revealed that in d1X, group I significantly varied from group II ( $p=0.0007)$, group III (0.0004), group IV $(p=0.00)$. In $d 2 X$, group I significantly varied with group II $(p=0.006)$ and group IV ( $p=0.0002)$. In $d 3 X$, group I significantly varied with group II $(p=0.005)$, group III $(p=0.001)$, group IV $(\mathrm{p}=0.001)$, and control group $(\mathrm{p}<0.01)$.

Tables 4, 5, and Graph 2 show differences ( $\mathrm{mm})$ in interimplant distance measured in the Y-axis. In $\Delta \mathrm{d} 1 \mathrm{Y}$, the group IV $(\Delta \mathrm{d} 1 \mathrm{Y}=0.03)$ had least mean difference followed by group III $(\Delta \mathrm{d} 1 \mathrm{Y}=0.18)$, group II $(\Delta \mathrm{d} 1 \mathrm{Y}=0.28)$, and group I $(\Delta \mathrm{d} 1 \mathrm{Y}=2.4)$. In $\Delta \mathrm{d} 2 \mathrm{Y}$, group IV $(\Delta \mathrm{d} 2 \mathrm{Y}=0.26)$ had least mean difference followed by group III $(\Delta \mathrm{d} 2 \mathrm{Y}=$ $0.514)$, group II $(\Delta d 2 Y=0.516)$, and group $\mathrm{I}(\Delta \mathrm{d} 2 \mathrm{Y}=3.85)$. The post hoc test revealed that in $\Delta \mathrm{d} 1 \mathrm{Y}$, intergroup comparison revealed statistically insignificant result. In $\mathrm{d} 2 \mathrm{Y}$,

Table 2: Intergroup statistical comparison using ANOVA and post hoc test for $\mathrm{D} 2 \mathrm{X}$ values

\begin{tabular}{|c|c|c|c|}
\hline \multirow[b]{2}{*}{ Groups } & \multirow{2}{*}{$\frac{D 2 X}{M e a n \pm S D}$} & \multirow{2}{*}{$\begin{array}{l}\text { ANOVA } \\
\text { test }\end{array}$} & \multirow[b]{2}{*}{$p$-value } \\
\hline & & & \\
\hline Group I (closed tray) & $38.64 \pm 1.31$ & 7.35 & 0.0002 \\
\hline Group II (open tray) & $36.92 \pm 1.16$ & & \\
\hline Group III (acrylic splint) & $36.73 \pm 1.07$ & & \\
\hline Group IV (light cured) & $36.31 \pm 0.48$ & & \\
\hline Group V (control) & $36.1 \pm 0$ & & \\
\hline
\end{tabular}

Tukey honest significant difference post hoc test; SD: Standard deviation; Groups I vs II: Diff $=1.7200,95 \%$ confidence interval $(\mathrm{Cl})$ $=-3.0722$ to $-0.3678, p=0.0069$; Groups I vs III: Diff = 1.9100, $95 \% \mathrm{Cl}=-3.2622$ to $-0.5578, \mathrm{p}=0.0023$; Groups I vs IV: Diff = $2.3300,95 \% \mathrm{Cl}=-3.6822$ to $-0.9778, \mathrm{p}=0.0002$; Groups I vs V: Diff $=2.5400,95 \% \mathrm{Cl}=-5.7112$ to $0.6312, \mathrm{p}=0.1686$; Groups II vs III: Diff $=0.1900,95 \% \mathrm{Cl}=-1.5422$ to $1.1622, p=0.9942$; Groups II vs IV: Diff $=0.6100,95 \% \mathrm{Cl}=-1.9622$ to $0.7422, \mathrm{p}=$ 0.6958; Groups II vs V: Diff $=0.8200,95 \% \mathrm{Cl}=-3.9912$ to 2.3512 , $\mathrm{p}=0.9450$; Groups III vs IV: Diff $=0.4200,95 \% \mathrm{Cl}=-1.7722$ to $0.9322, \mathrm{p}=0.8981$; Groups III vs V: Diff $=0.6300,95 \% \mathrm{Cl}=$ -3.8012 to $2.5412, p=0.9786$; Groups IV vs V: Diff $=0.2100$, $95 \% \mathrm{Cl}=-3.3812$ to $2.9612, \mathrm{p}=0.9997$ 
Table 3: Intergroup statistical comparison using ANOVA and post hoc test for D3X values

\begin{tabular}{|c|c|c|c|}
\hline \multirow[b]{2}{*}{ Groups } & $D 3 X$ & \multirow{2}{*}{$\begin{array}{l}\text { ANOVA } \\
\text { test }\end{array}$} & \multirow[b]{2}{*}{$p$-value } \\
\hline & Mean $\pm S D$ & & \\
\hline Group I (closed tray) & $39.9 \pm 0.92$ & 7.99 & $<0.01$ \\
\hline Group II (open tray) & $41.78 \pm 1.48$ & & \\
\hline Group III (acrylic splint) & $41.98 \pm 1.59$ & & \\
\hline Group IV (light cured) & $42.05 \pm 0.94$ & & \\
\hline Group V (control) & $42.53 \pm 0$ & & \\
\hline
\end{tabular}

Tukey honest significant difference post hoc test; SD: Standard deviation; Groups I vs II: Diff $=1.8800,95 \%$ confidence interval $(\mathrm{Cl})=0.4369$ to 3.3231, $\mathrm{p}=0.0050$; Groups I vs III: Diff $=2.0800$, $95 \% \mathrm{Cl}=0.6369$ to $3.5231, \mathrm{p}=0.0016$; Groups I vs IV: Diff $=$ 2.1500, $95 \% \mathrm{Cl}=0.7069$ to $3.5931, p=0.0010$; Groups I vs V: Diff $=2.6300,95 \% \mathrm{Cl}=1.1869$ to $4.0731, \mathrm{p}=0.0000$; Groups II vs III: Diff $=0.2000,95 \% \mathrm{Cl}=-1.2431$ to $1.6431, p=0.9947$; Groups II vs IV: Diff $=0.2700,95 \% \mathrm{Cl}=-1.1731$ to $1.7131, \mathrm{p}=$ 0.9836; Groups II vs V: Diff $=0.7500,95 \% \mathrm{Cl}=-0.6931$ to 2.1931 , $p=0.5825$; Groups III vs IV: Diff $=0.0700,95 \% \mathrm{Cl}=-1.3731$ to 1.5131, $p=0.9999$; Groups III vs V: Diff $=0.5500,95 \% \mathrm{Cl}=$ -0.8931 to $1.9931, \mathrm{p}=0.8143$; Groups IV vs V: Diff $=0.4800$ $95 \% \mathrm{Cl}=-0.9631$ to $1.9231, \mathrm{p}=0.8776$

group I significantly varied with group II ( $\mathrm{p}=0.01)$, group III ( $\mathrm{p}=0.0005)$, group IV $(0.001)$, but insignificant results were seen with the control group ( $p>0.01$ ).

Tables 6 to 8 and Graph 3 show differences $(\mathrm{mm})$ in interimplant distance measured in the Z-axis. In $\Delta \mathrm{d} 1 \mathrm{Z}$, group IV $(\Delta \mathrm{d} 1 \mathrm{Z}=-0.09)$ had least mean difference followed by group III $\Delta \mathrm{d} 1 \mathrm{Z}=0.21)$, group II $(\Delta \mathrm{d} 1 \mathrm{Z}=0.32)$, and group I $(\Delta \mathrm{d} 1 \mathrm{Z}=0.71)$. In $\Delta \mathrm{d} 2 \mathrm{Z}$, group IV $(\Delta \mathrm{d} 2 \mathrm{Z}=$ $0.05)$ had least mean difference followed by group III $(\Delta \mathrm{d} 2 \mathrm{Z}=0.10)$, group II $(\Delta \mathrm{d} 2 \mathrm{Z}=0.11)$, and group I $(\Delta \mathrm{d} 2 \mathrm{Z}$ $=0.16) \cdot \operatorname{In} \Delta \mathrm{d} 3 \mathrm{Z}$, group IV $(\Delta \mathrm{d} 3 \mathrm{Z}=-0.070)$ had least mean difference followed by group III $(\Delta \mathrm{d} 3 \mathrm{Z}=0.13)$, group II $(\Delta \mathrm{d} 3 \mathrm{Z}=0.21)$, and group $\mathrm{I}(\Delta \mathrm{d} 3 \mathrm{Z}=1.04)$. The post hoc test

Table 4: Intergroup statistical comparison using ANOVA and post hoc test for D1Y values

\begin{tabular}{|c|c|c|c|}
\hline & $D 1 Y$ & ANOVA & \\
\hline Groups & Mean $\pm S D$ & test & $p$-value \\
\hline Group I (closed tray) & $23.83 \pm 2.95$ & 2.83 & 0.04 \\
\hline Group II (open tray) & $21.68 \pm 1.48$ & & \\
\hline Group III (acrylic splint) & $21.58 \pm 1.51$ & & \\
\hline Group IV (light cured) & $21.43 \pm 0.87$ & & \\
\hline Group V (control) & $21.4 \pm 0$ & & \\
\hline
\end{tabular}

Tukey honest significant difference post hoc test; SD: Standard deviation; Groups I vs II: Diff $=2.1500,95 \%$ confidence interval $(\mathrm{Cl})=-4.5459$ to $0.2459, \mathrm{p}=0.0964$; Groups I vs III: Diff $=2.2500$, $95 \% \mathrm{Cl}=-4.6459$ to $0.1459, \mathrm{p}=0.0744$; Groups I vs IV: Diff $=$ $2.4000,95 \% \mathrm{Cl}=-4.7959$ to $-0.0041, \mathrm{p}=0.0494$; Groups I vs V: Diff $=2.4300,95 \% \mathrm{Cl}=-8.0489$ to $3.1889, \mathrm{p}=0.7275$; Groups II vs III: Diff $=0.1000,95 \% \mathrm{Cl}=-2.4959$ to $2.2959, \mathrm{p}=1.0000$; Groups II vs IV: Diff $=0.2500,95 \% \mathrm{Cl}=-2.6459$ to $2.1459, \mathrm{p}=$ 0.9982; Groups II vs V: Diff $=0.2800,95 \% \mathrm{Cl}=-5.8989$ to 5.3389 , $\mathrm{p}=0.9999$; Groups III vs IV: Diff $=0.1500,95 \% \mathrm{Cl}=-2.5459$ to 2.2459, $\mathrm{p}=0.9998$; Groups III vs V: Diff $=0.1800,95 \% \mathrm{Cl}=$ -5.7989 to $5.4389, p=1.0000$; Groups IV vs V: Diff $=0.0300$, $95 \% \mathrm{Cl}=-5.6489$ to $5.5889, \mathrm{p}=0.8017$

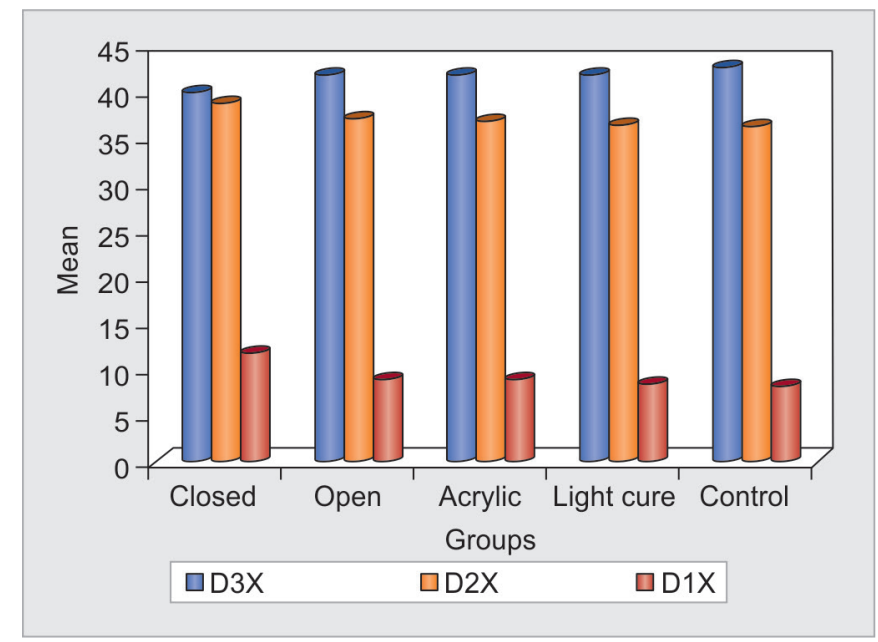

Graph 1: Statistical mean values of D3X, D2X, and D1X variables for five groups measured in the $X$-axis

revealed that in $\mathrm{d} 1 \mathrm{Z}$, group I significantly varied with group II $(\mathrm{p}=0.003)$ and group III $(\mathrm{p}<0.01)$, group IV $(\mathrm{p}<0.01)$ and the control group $(\mathrm{p}=0.03)$. In $\mathrm{d} 2 \mathrm{Z}$, intergroup comparison revealed statistically insignificant result. In $\mathrm{d} 3 \mathrm{Z}$, group I significantly varied with group II $(p=0.03)$, group III $(p=0.01)$, and group IV $(p=0.008)$.

From the above results, it can be well appreciated that the casts obtained from copings splinted with light cure resin tray material were similar to the reference model, followed by those obtained from splinted acrylic resin, those made with open-tray impression technique, and finally, the most variant closed-tray impression technique.

\section{CONCLUSION}

Within certain limitations, a final conclusion was drawn that when comparison of impressions made

Table 5: Intergroup statistical comparison using ANOVA and post hoc test for $\mathrm{D} 2 \mathrm{Y}$ values

\begin{tabular}{llll}
\hline & \multicolumn{1}{c}{$D 2 Y$} & \multicolumn{2}{c}{ ANOVA } \\
Groups & Mean $\pm S D$ & test & $p$-value \\
\hline Group I (closed tray) & $25.86 \pm 3.13$ & 6.74 & $<0.01$ \\
Group II (open tray) & $22.52 \pm 2.26$ & & \\
Group III (acrylic splint) & $21.49 \pm 1.56$ & & \\
Group IV (light cured) & $21.74 \pm 0.97$ & & \\
Group V (control) & $22.004 \pm 0$ & & \\
\hline
\end{tabular}

Tukey honest significant difference post hoc test; SD: Standard deviation; Groups I vs II: Diff $=3.3400,95 \%$ confidence interval $(\mathrm{Cl})$ $=-6.0845$ to $-0.5955, p=0.0105$; Groups I vs III: Diff = 4.3700, $95 \% \mathrm{Cl}=-7.1145$ to $-1.6255, \mathrm{p}=0.0005$; Groups I vs IV: Diff $=$ $4.1200,95 \% \mathrm{Cl}=-6.8645$ to $-1.3755, \mathrm{p}=0.0011$; Groups I vs V: Diff $=3.8560,95 \% \mathrm{Cl}=-10.2925$ to $2.5805, p=0.4350$; Groups II vs III: Diff $=1.0300,95 \% \mathrm{Cl}=-3.7745$ to $1.7145, \mathrm{p}=0.8168$; Groups II vs IV: Diff $=0.7800,95 \% \mathrm{Cl}=-3.5245$ to $1.9645, \mathrm{p}=$ 0.9240; Groups II vs V: Diff $=0.5160,95 \% \mathrm{Cl}=-6.9525$ to 5.9205 , $\mathrm{p}=0.9993$; Groups III vs IV: Diff $=0.2500,95 \% \mathrm{Cl}=-2.4945$ to 2.9945, $\mathrm{p}=0.9989$; Groups III vs V: Diff $=0.5140,95 \% \mathrm{Cl}=$ -5.9225 to $6.9505, p=0.9994$; Groups IV vs V: Diff $=0.2640$, $95 \% \mathrm{Cl}=-6.1725$ to $6.7005, \mathrm{p}=1.0000$ 


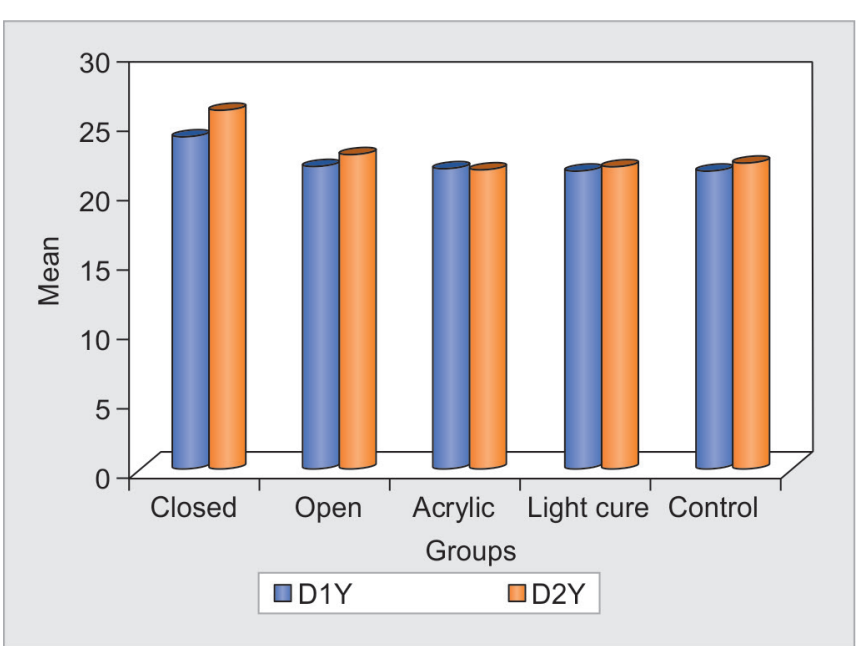

Graph 2: Statistical mean values of D1Y and D2Y variables for five groups measured in the $Y$-axis

with nonsplinted and splinted copings was done, the casts obtained from splinted copings were closer to the reference model as compared with the nonsplinted group.

When impressions made with open-tray with splinting, open-tray without splinting, and closed-tray impression technique were compared, the casts obtained from open-tray splinted group were closer to the reference model as compared with other groups.

Light cure splinted copings resembled reference model the most as compared with those splinted with autopolymerizing acrylic resin. The intercomparison of open-tray and closed-tray technique revealed that the casts obtained from closed-tray impression technique varied the most from the reference model.

Table 7: Intergroup statistical comparison using ANOVA and post hoc test for D2Z values

\begin{tabular}{|c|c|c|c|}
\hline & $D 2 Z$ & ANOVA & \\
\hline Groups & Mean $\pm S D$ & test & $p$-value \\
\hline Group I (closed tray) & $0.21 \pm 0.09$ & 1.36 & 0.27 \\
\hline Group II (open tray) & $0.16 \pm 0.14$ & & \\
\hline Group III (acrylic splint) & $0.15 \pm 0.13$ & & \\
\hline Group IV (light cured) & $0.1 \pm 0.09$ & & \\
\hline Group V (control) & $0.05 \pm 0$ & & \\
\hline
\end{tabular}

Tukey honest significant difference post hoc test; SD: Standard deviation; Groups I vs II: Diff $=0.0500,95 \%$ confidence interval $(\mathrm{Cl})=-0.1974$ to $0.0974, p=0.8650$; Groups I vs III: Diff $=0.0600$, $95 \% \mathrm{Cl}=-0.2074$ to $0.0874, \mathrm{p}=0.7687$; Groups I vs IV: Diff $=$ $0.1100,95 \% \mathrm{Cl}=-0.2574$ to $0.0374, \mathrm{p}=0.2247$; Groups I vs V: Diff $=0.1600,95 \% \mathrm{Cl}=-0.5056$ to $0.1856, p=0.6753$; Groups II vs III: Diff $=0.0100,95 \% \mathrm{Cl}=-0.1574$ to $0.1374, p=0.9997$; Groups II vs IV: Diff $=0.0600,95 \% \mathrm{Cl}=-0.2074$ to $0.0874, \mathrm{p}=$ 0.7687 ; Groups II vs V: Diff $=0.1100,95 \% \mathrm{Cl}=-0.4556$ to 0.2356 , $\mathrm{p}=0.8897$; Groups III vs IV: Diff $=0.0500,95 \% \mathrm{Cl}=-0.1974$ to $0.0974, p=0.8650$; Groups III vs V: Diff $=0.1000,95 \% \mathrm{Cl}=$ -0.4456 to $0.2456, p=0.9193$; Groups IV vs 5: Diff $=0.0500$, $95 \% \mathrm{Cl}=-0.3956$ to $0.2956, p=0.9935$
Table 6: Intergroup statistical comparison using ANOVA and post hoc test for $\mathrm{D} 1 \mathrm{Z}$ values

\begin{tabular}{|c|c|c|c|}
\hline \multirow[b]{2}{*}{ Groups } & $D 1 Z$ & \multirow{2}{*}{$\begin{array}{l}\text { ANOVA } \\
\text { test }\end{array}$} & \multirow[b]{2}{*}{$p$-value } \\
\hline & Mean $\pm S D$ & & \\
\hline Group I (closed tray) & $0.86 \pm 0.35$ & 11.34 & $<0.01$ \\
\hline Group II (open tray) & $0.47 \pm 0.21$ & & \\
\hline Group III (acrylic splint) & $0.36 \pm 0.17$ & & \\
\hline Group IV (light cured) & $0.24 \pm 0.07$ & & \\
\hline Group V (control) & $0.15 \pm 0$ & & \\
\hline
\end{tabular}

Tukey honest significant difference post hoc test; SD: Standard deviation; Groups I vs II: Diff $=0.3900,95 \%$ confidence interval $(\mathrm{Cl})=-0.6774$ to $-0.1026, \mathrm{p}=0.0035$; Groups I vs III: Diff $=$ $0.5000,95 \% \mathrm{Cl}=-0.7874$ to $-0.2126, \mathrm{p}=0.0001$; Groups I vs IV: Diff $=0.6200,95 \% \mathrm{Cl}=-0.9074$ to $-0.3326, p=0.0000$; Groups I vs V: Diff $=0.7100,95 \% \mathrm{Cl}=-1.3839$ to $-0.0361, \mathrm{p}=0.0347$; Groups II vs III: Diff $=0.1100,95 \% \mathrm{Cl}=-0.3974$ to $0.1774, p=$ 0.8059 ; Groups II vs IV: Diff $=0.2300,95 \% \mathrm{Cl}=-0.5174$ to 0.0574 , $\mathrm{p}=0.1691$; Groups II vs V: Diff $=0.3200,95 \% \mathrm{Cl}=-0.9939$ to $0.3539, p=0.6544$; Groups III vs IV: Diff $=0.1200,95 \% \mathrm{Cl}=$ -0.4074 to $0.1674, p=0.7520$; Groups III vs V: Diff $=0.2100$, $95 \% \mathrm{Cl}=-0.8839$ to $0.4639, \mathrm{p}=0.8970$; Groups IV vs V: Diff $=$ $0.0900,95 \% \mathrm{Cl}=-0.7639$ to $0.5839, \mathrm{p}=0.9952$

\section{CLINICAL SIGNIFICANCE}

Accurate making of a multi-implant impression is a challenging task because of complexity in attaining the "passive fit" of the prostheses, which is directly related to the accurate transfer of 3D spatial arrangements of implants to the cast. The multiple implants dispersed along the dental arch result in inaccuracy in impression. ${ }^{3}$ Most studies which investigated the effect of impression techniques on implant impression accuracy were performed with two implants, ${ }^{4-9}$ except for a few authors who studied the effect using three to five implants. ${ }^{10-12}$ The present study evaluated the accuracy of impression

Table 8: Intergroup statistical comparison using ANOVA and post hoc test for $\mathrm{D} 3 \mathrm{Z}$ values

\begin{tabular}{|c|c|c|c|}
\hline & $D 3 Z$ & ANOVA & \\
\hline Groups & Mean $\pm S D$ & test & $p$-value \\
\hline Group I (closed tray) & $-2.41 \pm 0.88$ & 4.36 & 0.006 \\
\hline Group II (open tray) & $-1.58 \pm 0.53$ & & \\
\hline Group III (acrylic splint) & $-1.5 \pm 0.48$ & & \\
\hline Group IV (light cured) & $-1.44 \pm 0.41$ & & \\
\hline Group V (control) & $-1.37 \pm 0$ & & \\
\hline
\end{tabular}

Tukey honest significant difference post hoc test; SD: Standard deviation; Groups I vs II: Diff $=0.8300,95 \%$ confidence interval $(C I)=0.0560$ to $1.6040, p=0.0304$; Groups I vs III: Diff $=0.9100$, $95 \% \mathrm{Cl}=0.1360$ to $1.6840, \mathrm{p}=0.0144$; Groups I vs IV: Diff $=$ $0.9700,95 \% \mathrm{Cl}=0.1960$ to $1.7440, \mathrm{p}=0.0080$; Groups I vs V: Diff $=1.0400,95 \% \mathrm{Cl}=-0.7752$ to $2.8552, \mathrm{p}=0.4797$; Groups II vs III: Diff $=0.0800,95 \% \mathrm{Cl}=-0.6940$ to $0.8540, p=0.9982$; Groups II vs IV: Diff $=0.1400,95 \% \mathrm{Cl}=-0.6340$ to $0.9140, \mathrm{p}=$ 0.9848; Groups II vs V: Diff $=0.2100,95 \% \mathrm{Cl}=-1.6052$ to 2.0252 , $\mathrm{p}=0.9973$; Groups III vs IV: Diff $=0.0600,95 \% \mathrm{Cl}=-0.7140$ to $0.8340, p=0.9994$; Groups III vs V: Diff $=0.1300,95 \% \mathrm{Cl}=$ -1.6852 to $1.9452, p=0.9996$; Groups IV vs V: Diff $=0.0700$, $95 \% \mathrm{Cl}=-1.7452$ to $1.8852, \mathrm{p}=1.0000$ 


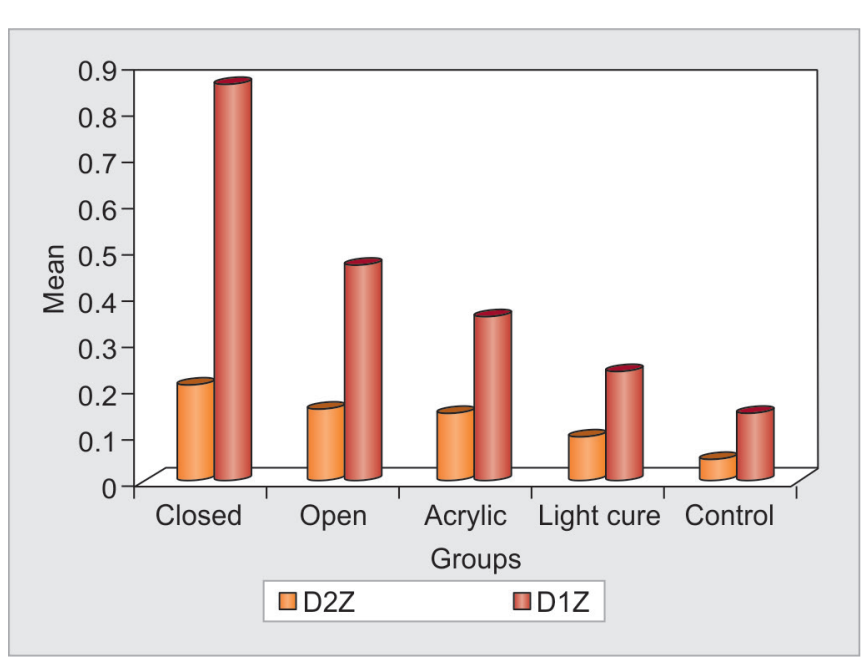

Graph 3: Statistical mean values of D3Z, D2Z, and D1Z variables for five groups measured in the Z-axis

making on multiunit implants as a correlation was seen between impression inaccuracy and increased number of implants.

The accuracy of the multiple implant impression is influenced by the type of impression material used which ultimately leads to an accurate cast on which precisely fitting prosthesis is fabricated. Several factors including material accuracy, time span before the impression is poured, and extent of intraoral undercuts are to be kept in mind while choosing an impression material. To summarize, it appears that various impression materials and combination of materials were tested and recommended in the dental literature. Irreversible hydrocolloid, impression plaster, polyether, condensation and addition silicones, and polysulfide materials have been used in different consistencies and combinations. Addition silicones have better modulus of elasticity, which allows easier removal of the impression; ${ }^{13}$ one study found that there was no significant difference between polyether and polyvinyl siloxane. ${ }^{14}$ Moreover, it has been recommended in edentulous patient, and also the economical cost factor and ease of manipulation make it a material of choice. So, in this study, addition silicone impression material is used for multiple implant impressions of edentulous patients.

There are two primary implant impression techniques, the direct or open-tray technique and the indirect or closed-tray technique. In the open-tray technique, impression copings are fastened to the implant with a screw that is extended above the coping through an opening made in a custom tray (also called open-tray technique or direct technique). When the material is set, the screw is loosened and the tray is removed from the mouth with the impression copings logged within the impression. An implant analog is screwed to the impression coping and a working cast is poured.$^{15}$ The open-tray technique allows the impression copings to remain inside the impression.
This decreases the effect of the implant angulations, material deformation upon recovering impression from the mouth, and there is no need to place the coping back into the original position..$^{12}$ A disadvantage of this technique is that some rotational movement of the coping may occur when attaching the implant analog. ${ }^{15}$

There have been different studies that compared the open-tray and closed-tray impression accuracies. Most of the studies favored the open-tray technique for multiple implants. ${ }^{15-18}$ In this study, casts fabricated from splinted implant impression copings were more close to the reference model than the nonsplinted group. The reason for this is that the splinted impression copings have less chances of movement. Vigolo et $\mathrm{al}^{19}$ also observed in their study that impression copings splinted with autopolymerizing resin or those abraded with silica and coated with impression adhesive before impression making result in more precise details. Lahori et $\mathrm{al}^{3}$ also found similar results in their study. However, few authors found that nonsplint technique is better. ${ }^{20-22}$ Distortion in splinted transfer techniques can be because of difference in dimensional accuracy of the materials used for splinting. This could be due to large amount of autopolymerizing acrylic resin used without sectioning and resplinting, leading to increased distortion because of polymerization shrinkage.

\section{REFERENCES}

1. Goodacre CJ, Bernal G, Rungcharassaeng K, Kan JY. Clinical complications with implants and implant prostheses. J Prosthet Dent 2003 Aug;90(2):121-132.

2. Linkevicius T, Svediene O, Vindasiute E, Puisys A, Linkeviciene $\mathrm{L}$. The influence of implant placement depth and impression material on the stability of an open tray impression coping. J Prosthet Dent 2012 Oct;108(4):238-243.

3. Lahori M, Mahesh L, Nagrath R, Singh S. An evaluation of the accuracy of multiple implant impression techniques: an in vitro study. J Implants Adv Clin Dent 2012 May-Jun;4(3):57-69.

4. Gallucci GO, Papaspyridakos P, Ashy LM, Kim GE, Brady NJ, Weber H. Clinical accuracy outcome of closed tray and open tray implant impression technique for partially edentulous patients. Int J Prosthodont 2011 Sep-Oct;24(5):469-472.

5. Rutkunas V, Sveigata K, Savickas R. Effects of implant angulation, material selection, and impression technique on impression accuracy: a preliminary laboratory study. Int J Prosthodont 2012 Sep-Oct;25(5):512-515.

6. Filho HG, Mazaro JV, Vedovatto E, Assuncao WG, Santos PH. Accuracy of impression techniques for implants. Part 2comparison of splinting techniques. J Prosthodont 2008 Feb;18(2):172-176.

7. Choi JH, Lim YJ, Yim SH, Kim CW. Evaluation of the accuracy of implant-level impression techniques for internal-connection implant prostheses in parallel and divergent models. Int J Oral Maxillofac Implants 2007 Sep-Oct;22(5):761-768.

8. Assuncao WG, Tabata LF, Cardoso A, Rocha EP, Gomes EA. Prosthetic transfer impression accuracy evaluation for osseointegrated implants. Implant Dent 2008 Sep;17(3):248-256. 
9. Jang HS, Kim S, Shim JS, Lee KW, Moon HS. Accuracy of impressions for internal-connection implant prostheses with various divergent angles. Int J Oral Maxillofac Implants 2011 Sep-Oct;26(5):1011-1015.

10. Sorrentino R, Gherlone EF, Calesini G, Zarone F. Effect of implant angulation, connection length, and impression material on the dimensional accuracy of implant impressions: an in-vitro comparative study. Clin Implant Dent Relat Res 2010 May;12(Suppl 1):e63-e76.

11. Jo SH, Kim KI, Seo JM, Song KY, Park JM, Ahn SG. Effect of impression coping and implant angulation on the accuracy of implant impressions: an in-vitro study. J Adv Prosthodont 2010 Dec;2(4):128-133.

12. Conrad HJ, Pesun IJ, DeLong R, Hodges JS. Accuracy of two impression techniques with angulated implants. J Prosthet Dent 2007 Jun;97(6):349-356.

13. Chai J, Takahashi Y, Lautenschlager EP. Clinically relevant mechanical properties of elastomeric impression materials. Int J Prosthodont 1998 May-Jun;11(3):219-223.

14. Liou AD, Nicholls JI, Yuodelis RA, Brudvik JS. Accuracy of replacing three tapered transfer impression copings in two elastomeric impression materials. Int J Prosthodont 1993 Jul-Aug;6(4):377-383.

15. Carr AB. Comparison of impression techniques for a twoimplant 15-degree divergent model. Int J Oral Maxillofac Implants 1992 Winter;7(4):468-475.
16. Daoudi MF, Setchell DJ, Searson LJ. An evaluation of three implant level impression techniques for single tooth implant. Eur J Prosthodont Restor Dent 2004 Mar;12(1):9-14.

17. Shankar YR, Sahoo S, Krishna MH, Kumar PS, Kumar TS, Narula S. Accuracy of implant impressions using various impression techniques and impression materials. J Dent Implants 2016 Sep;6(1):29-36.

18. Del'Acqua MA, Arioli-Filho JN, Compagnoni MA, Mollo Fde A Jr. Accuracy of impression and pouring techniques for an implant-supported prosthesis. Int J Oral Maxillofac Implants 2008 Mar-Apr;23(2):226-236.

19. Vigolo P, Majzoub Z, Cordioli G. Evaluation of the accuracy of three techniques used for multiple implant abutment impressions. J Prosthet Dent 2003 Feb;89(2):186-192.

20. Del Acqua MA, Chavez AM, CastanharoSM, Compagnoni MA, Mollo Fde A Jr. The effect of splint material rigidity in implant impression techniques. Int J Oral Maxillofac Implants 2010 Nov-Dec;25(6):1153-1158.

21. Burawi G, Houston F, Byrne D, Claffey N. A comparison of the dimensional accuracy of the splinted and unsplinted impression techniques for the Bone-Lock implants system. J Prosthet Dent 1997 Jan;77(1):68-75.

22. Inturregui JA, Aquilino SA, Ryther JS, Lund PS. Evaluation of three impression techniques for osseointegrated oral implants. J Prosthet Dent 1993 May;69(5):503-509. 